\title{
DISIPLIN PADA ANAK USIA SEKOLAH
}

\author{
Oleh: \\ R. Firman Nurbudi P. \\ Fakultas Keguruan dan Ilmu Pendidikan, Universitas Wiraraja Sumenep
}

\begin{abstract}
ABSTRAK
Pendidikan merupakan salah satu faktor dalam perkembangan kepribadian peserta didik. Pendidikan bertujuan untuk berkembangnya potensi peserta didik agar menjadi manusia yang beriman dan bertaqwa kepada Tuhan YME, berakhlak mulia, sehat, berilmu, cakap, kreatif, mandiri, dan menjadi warga negara yang demokratis serta bertanggung jawab. Agar tercipta pendidikan yang bertujuan seperti pada UU nomor 20 tahun 2003, diperlukan sikap yang dapat membantu terlaksananya tujuan tersebut. Sikap dasar manusia terutama pada peserta didik tidak terlepas dari unsur karakter yang terdapat pada individu. Unsur dari karakter peserta didik yang perlu dikembangkan adalah sikap disiplin. Sikap disiplin diperlukan sebagai pondasi dalam pembelajaran di sekolah. Pondasi disiplin yang baik diharapkan akan membentuk keserasian sikap dan tindakan peserta didik.
\end{abstract}

Kata Kunci: Disiplin, Anak Usia Sekolah

\section{PENDAHULUAN}

Pengembangan diri merupakan tuntutan dan kebutuhan manusia selaku makhluk yang pajuling sempurna dibandingkan dengan makhluk yang lain. Kebutuhan yang urgent pada saat ini adalah pendidikan. Pendidikan dianggap sebagai kebutuhan terpenting pada masa sekarang karena merupakan suatu upaya manusia agar dapat memajukan dan mengembangkan pribadinya atau faktor non-fisik selain faktor kebutuhan pokok lain yang menyangkut pemenuhan kebutuhan fisik.

Seiring dengan diperlukannya pendidikan sebagai suatu upaya untuk mengembangkan potensi pada diri manusia, maka pemerintah selaku pembuat regulasi dalam pendidikan telah menetapkan tujuan pendidikan bahwa pendidikan untuk mengembangkan potensi peserta didik agar menjadi manusia yang beriman dan bertaqwa kepada Tuhan YME, berakhlak mulia, sehat, berilmu, cakap, kreatif, mandiri, dan menjadi warga negara yang demokratis serta bertanggung jawab, serta berfungsi mengembangkan kemampuan dan membentuk watak serta peradaban bangsa yang bermartabat dalam rangkan mencerdaskan kehidupan bangsa (UU Sisdiknas 20/ 2003:5).

Seperti diketahui bahwa masa atau usia yang paling sering menjadi pelaku di dalam sekolah adalah anak-anak terutama bagi mereka yang telah mencapai usia sekolah. Anak usia sekolah dasar berada pada rentang usia 7-12 tahun atau telah memasuki sekolah dasar (anak-anak ke remaja awal). Anak-anak usia ini lebih cepat tumbuh baik secara fisik maupun kognitif, meskipun pertumbuhannya lebih lambat daripada anak usia dini (Danim, 2011:60). Sedangkan untuk anak usia sekolah menengah berada pada rentang usia 12-19 atau telah memasuki usia sekolah menengah pertama dan sekolah menengah atas. Selama periode masa ini pertumbuhan fisik, emosional, dan intelektual terjadi dengan kecepatan yang memusingkan, menantang peserta didik sebagai remaja untuk menyesuaikan diri dengan suatu bentuk tubuh baru, identitas sosial, dan memperluas pandangannya tentang dunia (Danim, 2011:76).

Anak pada masa pertumbuhan di periode usia sekolah (7-19 tahun), mengalami pertumbuhan yang pesat. 
Pertumbuhan baik dari aspek fisik maupun non fisik. Perkembangan non fisik diantaranya faktor emosi. Mereka mulai belajar mengendalikan emosinya yang mulai berubah.

Emosi merupakan faktor dominan yang memengaruhi tingkah laku individu, dalam hal ini termasuk pula perilaku belajar (Yusuf, 2011:64). Emosi yang positif akan memengaruhi individu untuk lebih dapat mengonsentrasikan dirinya terhadap aktivitas belajar dan disiplin dalam belajar (Yusuf, 2011:72).

Emosi positif tersebut tidak terlepas dari perilaku yang dipengaruhi oleh hereditas. Hereditas yang berhubungan dengan emosi terkait dengan karakter bahwa perkembangan karakter dipengaruhi pula oleh adanya emosi seseorang. Karena karakter dipengaruhi oleh hereditas yang turun dari orang tua mereka, namun faktor lingkungan mendukung perkembangan karakter tersebut. Karakter dimaknai sebagai nilai dasar yang membangun pribadi seseorang, terbentuk karena pengaruh hereditas maupun pengaruh lingkungan, yang dapat membedakan seseorang dengan orang lain, serta diwujudkan dalam sikap dan perilaku pada kehidupan sehari-hari (Samani, 2012:43).

Karakter tidak dapat dipisahkan dari diri individu. Karakter terbangun dari beberapa sikap mendasarinya. Karakter merupakan sifat-sifat kejiwaan, akhlak atau budi pekerti yang membedakan seseorang dengan yang lain (KBBI dalam Samani, 2012:42). Diantara sikap tersebut salah satunya adalah disiplin diri. Disiplin merupakan sikap atau kemampuan untuk mengontrol tindakan, perilaku, dan kebiasaan diri (Samani, 2012:130). Dengan demikian, sikap disiplin diperlukan sebagai penguat karakter individu agar lebih terarah dalam bertindak dan tercapai harapannya.

Mencermati uraian yang telah disampaikan, maka perlu ada perhatian terhadap sikap pada peserta didik mulai tingkat SD, SMP, maupun SMA. Sikap tersebut dalam hal ini adalah disiplin diri. Diharapkan sikap disiplin yang telah terinternalisasi dapat menunjang berkembangan karakter positif mereka.

\section{KARAKTERISTIK ANAK USIA SEKOLAH}

Rentang usia anak dalam masa sekolah berkisar 7-19 tahun, dimana perbedaan tumbuh dan berkembang terdapat di dalamnya. Untuk anak usia 712 tahun, mereka memasuki tingkat sekolah dasar. Ciri-ciri perkembangan anak pada usia ini meliputi:

1. Fisik-motorik, gerak atau aktivitas motorik yang lincah. Perkembangan fisik yang normal merupakan salah satu faktor penentu kelancaran pembelajaran, baik dalam pengetahuan maupun keterampilan;

2. Intelektual, anak sudah dapat mereaksi rangkaian intelektual, atau melaksanakan tugas-tugas belajar yang menuntut kemampuan kognitif (membaca, menulis, menghitung);

3. Bahasa, masa berkembangnya pesatnya kemampuan mengenal dan menguasai perbendaharaan kata;

4. Emosi, dia mulai belajar untuk mengendalikan dan mengontrol ekspresi emosinya. Kemampuan mengontrol emosi diperoleh melalui peniruan dan latihan. Emosi merupakan faktor dominan yang memengaruhi tingkah laku individu termasuk perilaku belajar;

5. Sosial, proses belajar untuk menyesuaikan diri dengan normanorma kelompok, tradisi, dan moral agama. Sanggup menyesuaikan diri dari sikap egosentris ke sikap sosiosentris;

6. Kesadaran beragama, kepercayaan kepada Tuhan pada usia ini bukan keyakinan hasil pemikiran, tetapi merupakan sikap emosi yang berhubungan erat dengan kebutuhan jiwa akan kasih saying dan perlindungan (Yusuf, 2011:59-69). 
Sedangkan anak usia 12-19 tahun, mereka memasuki tingkat sekolah menengah dengan ciri-ciri meliputi:

1. Fisik, mereka memasuki masa periode remaja transisi, yaitu periode transisi antara masa kanak-kanak dan usia dewasa.;

2. Kesehatan, masalah kesehatan sering berkorelasi dengan status sosial ekonomi yang rendah, pola makan yang buruk, dan perawatan kesehatan yang tidak memadai, berani mengambil kegiatan berisiko, masalah kepribadian, dan gaya hidup;

3. Kognitif, pada tahap ini menurut Piaget, mereka telah memasuki tahap operasi formal, di mana mereka mengembangkan alat baru untuk memanipulasi informasi. Mereka dapat mempertimbangkan kemungkinan masa depan, mencari jawaban, menangani masalah dengan fleksibel, menguji hipotesis, dan menarik kesimpulan atas kejadian yang mereka tidak mengalaminya;

4. Seksual, mereka berusaha secara total menemukan satu identitas, berupa perwujudan orientasi seksual yang tercermin dari hasrat seksual, emosional, romantik, dan atraksi kasih saying kepada anggota jenis kelamin yang berbeda;

5. Kenakalan remaja, tekanan teman sepermainan selama masa remaja terkadang begitu banyak sehingga remaja terlibat dalam tindakan antisocial berupa kenakalan (Danim, 2011:76-89).

Dari uraian yang disampaikan mengenai peserta didik yang memasuki tahap sekolah dasar dan menengah maka anak usia sekolah merupakan periode usia yang sudah mengetahui dan dapat berpikir secara abstrak mengenai kehidupan dirinya dan orang lain tentang peristiwa yang dijalani serta perihal orang lain, serta keadaan di lingkungannya.

Mereka sudah dapat menyesuaikan dan berpikir untuk dapat menyelesaikan permasalahannya sendiri dan cenderung mencari identitas akibat dari perubahan yang terjadi pada diri mereka baik secara fisik maupun non-fisik. Maka dari itu diperlukan suatu sikap dan tindakan yang konsisten pada diri mereka agar dapat menjaga keseimbangan dalam kehidupannya.

\section{KEKUATAN DISIPLIN}

Hal-hal yang mempengaruhi perkembangan anak usia sekolah terutama pada peserta didik yang bersekolah diperlukan sikap yang dapat menjaga dari keseimbangan antara pertumbuhan fisik dan non-fisik. Keseimbangan tersebut dapat diperoleh dengan tetap melaksanakan dan mentaati aturan atau berusaha mentaati sebuah aturan dan tatanan yang seharusnya dijalankan.

Suatu keseimbangan dapat terjadi bila individu konsisten dalam menjalankan suatu aturan atau tatanan yang semestinya. Sikap tersebut dapat dijalankan apabila individu menjalankannya dengan penuh kedisiplinan. Sikap disiplin diperlukan sebagai pengatur atau pengarah dalam mencapai suatu tujuan individu.

Disiplin mengacu pada instruksi diri untuk menyelesaikan tugas-tugas tertentu atau untuk mengadopsi pola perilaku tertentu, walaupun orang akan benarbenar agak kembali ke keadaan pasif atau non-termotivasi. Contoh disiplin adalah berkaitan dengan mempertahankan keinginan latihan atau belajar sehari-hari meskipun ingin melakukan sesuatu yang lain seperti menonton televisi atau berbaring di tempat tidur untuk waktu lama di pagi hari.

Salah satu faktor kunci untuk mencapai hasil yang sukses adalah kekuatan disiplin. Brian Tracy (dalam Kepelaris, 2010:332) menyatakan bahwa disiplin diri merupakan faktor kunci keberhasilan untuk mencapai tujuan seseorang dan tujuan. Disiplin diri didenifikan sebagai suatu kemampuan untuk membuat diri melakukan apa yang harus dilakukan ketika harus 
melakukannya. Selanjutnya Kapeleris (2010:332) menyampaikan bahwa disiplin memberikan kemampuan untuk mencapai hasil lebih cepat dari yang pernah dipikirkan.

Setelah menjadi orang yang sangat disiplin, maka dapat mengontrol diri dan kehidupan untuk mencapai tujuan yang dipikirkan sebelumnya tidak mungkin. Disiplin diri mengharuskan untuk membuat pengorbanan dalam jangka pendek sehingga mencapai keuntungan yang lebih besar dalam jangka panjang. Diperlukan tindakan yang pertama (menempatkan dalam upaya saat ini) dan menikmati manfaat nanti. Disiplin diri memungkinkan untuk menyelesaikan sejumlah kegiatan yang mencoba untuk dihindari.

\section{DISIPLIN PESERTA DIDIK DALAM PENDIDIKAN}

Konsep disiplin berkaitan dengan tata tertib, aturan, atau norma dalam kehidupan bersama (yang melibatkan orang banyak). Disiplin merupakan sikap atau kemampuan untuk mengontrol tindakan, perilaku, dan kebiasaan diri (Samani, 2012:130). Disiplin juga dapat diartikan sebagai suatu kepatuhan kepada aturan tata tertib, aturan, atau norma. Pengertian pelajar adalah manusia yang memasuki usia sekolah dan melakukan aktifitas belajar. Sedangkan pengertian peserta didik adalah pelajar atau manusia yang melakukan aktifitas belajar di sekolah atau pendidikan formal. Dengan demikian disiplin anak usia sekolah dapat disampaikan sebagai suatu sikap dan tindakan kepatuhan dari anak usia sekolah kepada aturan, tata tertib atau norma di lingkungan dan sekolahnya yang berkaitan dengan kegiatan belajar.

Dari pengertian tersebut dapat sedikit disampaikan bahwa, kedisiplinan anak usia sekolah dapat dilihat dari ketaatan (kepatuhan) siswa terhadap aturan (tata tertib) yang berkaitan dengan jam belajar di sekolah, yang meliputi jam masuk sekolah dan keluar sekolah, kepatuhan siswa dalam berpakaian, kepatuhan siswa dalam mengikuti kegiatan sekolah, dan lain sebagainya. Semua aktifitas siswa yang dilihat kepatuhannya adalah berkaitan dengan aktifitas pendidikan di sekolah, yang juga dikaitkan dengan kehidupan di lingkungan luar sekolah.

Dictionary of Education mengemukakan bahwa pendidikan adalah proses dimana seseorang mengembangkan kemampuan, sikap dan bentuk-bentuk dan tingkah lakunya di dalam masyarakat dimana dia hidup dan proses sosial dimana sesorang diharapkan pada pengaruh lingkungan yang terpilih dan terkontrol, sehingga dia dapat memperoleh atau mengalami perkembangan kemampuan sosial dan individu yang optimal.

Menurut Gagne (dalam Dahar, 2011:2), belajar dapat didefinisikan sebagai suatu proses di mana suatu organisasi berubah perilakunya sebagai akibat pengalaman. Pendidikan merupakan suatu upaya untuk menggali, mengarahkan, dan mengantarkan potensi yang terdapat pada peserta didik agar dapar hidup di lingkungannya serta dapat menempuh kehidupan yang lebih baik. Sesuai dengan UU Sisdiknas Nomor 20 Tahun 2003 bahwa pendidikan bertujuan untuk berkembangnya potensi peserta didik agar menjadi manusia yang beriman dan bertaqwa kepada Tuhan YME, berakhlak mulia, sehat, berilmu, cakap, kreatif, mandiri, dan menjadi warga negara yang demokratis serta bertanggung jawab.

Berdasarkan beberapa pengertian tersebut, dapat diberikan disampaikan unsur umum dalam pendidikan yaitu :

1. Pendidikan harus memiliki tujuan yang hakekatnya mengembangkan potensi individu yang bermanfaat bagi kehidupan pribadinya maupun lingkungannya.

2. Agar tercapai tujuan tersebut maka pendidikan perlu melakukan upaya yang disengaja dan terencana untuk 
memberikan bimbingan, pengajaran, dan pelatihan.

3. Kegiatan tersebut perlu diwujudkan pada semua lingkungan, baik formal, informal, dan non-formal.

\section{DAFTAR PUSTAKA}

Dahar, Ratna Wilis. 2011. Teori-Teori Belajar dan Pembelajaran. Jakarta: PT. Erlangga..

Danim, Sudarwan. 2011. Perkembangan Peserta Didik. Bandung: Penerbit Alfabeta.

Kapeleris, John. 2010: The Power of SelfDiscipline.(Online) http://johnkapeleris. com/blog/?p=332 diakses 12 Okt. 2012.

Kemdiknas. 2007. Undang-Undang Sisdiknas 2003. Jakarta: Sinar Grafika.

Samani, Muchlas; Hariyanto. 2012. Konsep dan Model Pendidikan Karakter. Bandung: PT. Remaja Rosdakarya.

Yusuf L.N., Syamsu; Sugandhi, Nani M. 2011. Perkembangan Peserta Didik. Jakarta: PT. RajaGrafindo Persada. 